\title{
The Constitution of Cultural Modernity
}

I.

The s single idear of culture, the problem of culture that Georg Lukács bequeathed to his Budapest pupils was one that Ferenc Feher, Agnes Heller and György Márkus were to address in different ways after their break with the ruling Soviet orthodoxy in Hungary and their emigration to Australia. The problem of culture, more exactly, the question of Enlightenment and culture became the primary focus of Márkus's work in Sydney. His theorization of modern culture as tied to the open articulation of the antinomies of modernity had as its immediate presupposition Márkus's seminal contribution in Budapest to the renewal of critical theory: Marxism and Anthropology. The Concept of "Human Essence" in the Philosophy of Marx (1978), followed by the further elucidation of the concept of human essence in terms of the paradigm of production in the late seventies. In Marxism and Anthropology, Márkus argued that Marx conceives species-essence as intersubjectivity, understood as the historically produced social totality that is the product of human labour and its teleological relation to

The essay situates György Markus's key writings on cultural modernity in relation to Kant and Hegel's conception of modern society as a society that knows itself as culture. The reconstruction of Markus's theory has the function of identifying new dimensions of his theory in relation to the tradition of modern cultural critique. Markus's rethinking of high culture in terms of the paradoxical unity of the arts and the sciences is central to his revision of this tradition. He replaces the totalizing narratives of the crisis of culture by the self-regulating constitution of a society of culture, which owes its vitality to the recurrent disputes between the Enlightenment and Romanticism. 
nature. The world that is given to humans is an already existing, historically produced objectivity, reproduced and changed through the process of appropriation that presupposes the selection of ends and means. Appropriation is therefore an open, undetermined process by which human essence - the human capacity to be, in Marx's words, a suniversal and therefore free being (Estranged Labour) - can unfold in and through social development. Once Marx's historically open conception of human essence is grasped, the mechanistic understanding of historical determinism is demolished and, as Márkus will go on to show in his acute analysis of Marx's practical-social rationality, the paradigm of production must be understood as a project that articulates human essence as a principally unlimited tendency for progress. Or more exactly, precisely qua project the paradigm of production is only one among competing historical alternatives in relation to social development. Marxism and Anthropology thus lays the groundwork in the 1960s for the ever more radical revisionism that culminates in the joint critique of the Soviet system of power in Dictatorship Over Needs by Feher, Heller and Márkus (1983) and in Márkus's elucidation of the paradigm of production in Marx. It is not by chance that Life and the Soul: The Young Lukacs and the Problem of Culture is the one essay from Márkus's Budapest years that is included in the most important collection of his Australian essays, Culture, Science, Society (2011). It forms the bridge between the legacy of Lukács and the enduring theme of Western Marxism - the crisis of culture in modernity - and the main concern of Márkus's work in Australia.

To understand the questions that Márkus's post-Marxist theory of cultural modernity seeks to answer, we need to go back to Lukács's pre-Marxist search for answers to the problem of culture in modernity. Life and Soul: The Young Lukács and the Problem of Culture is pivotal here. As indicated, the essay looks back to the ssingle idea of Lukács and Western Marxism - the problem of culture - and points forward to the > single idea of Márkus's work from the early 1980s on: what he was to call sthe constitution of cultural modernity ${ }^{1}{ }^{1}$ The Lukácsian problem of culture is transformed in Márkus into the paradoxical unity of culture. The problem of culture, so central to Lukács and Western Marxism, derives, however, from the paradoxes inherent in the Enlightenment conception of culture that were given their fundamental, foundational expression in Kant and Hegel.

The opposing conceptions of culture in Hegel and Kant - the philosophical-historical and the metaphysical - define the parameters of Lukács's problem of culture. If culture signified for Lukács the form that unifies all 
dimensions of life into a totality and if only in such an authentic totality can art and philosophy cease to be alienated from life, the deciding question of culture is this: Is a life free of alienation possible? „The issue«, in Márkus's words, »is whether the conditions of the age in which he [Lukács] lived was an expression of the existential and ontological tragedy of culture or of a historical crisis from which recovery was possible. $\aleph^{2}$ Ontological tragedy or historical crisis? Lukács's first answer was historical in the form of the comparison between classical tragedy and modern drama in History of Modern Drama (Die Entwicklungsgeschichte des modernen Dramas [1909]) and between Greek and Christian epic and the modern novel in The Theory of the Novel (Die Theorie des Romans [1916]), which was originally intended as the introduction to a study of Dostoevsky and his adumbration of a utopia of authentic life beyond alienation. Lukács's contrast between the organic totality of authentic culture and the fallen world of god-forsaken modernity demonstrates the historical reversal of the relationship between life and culture, life and the work of art. Authentic culture gave meaning to the work of art and in turn art gave the highest expression to the totality of life. In the condition of modern alienation, however, the artwork becomes the surrogate for the lost totality of the past. And as such it has a double role. On the one hand, it is called to give meaning here and now to alienated life by objectifying and giving form to the split between soul and world, individual and society, inner values and external institutions. On the other hand, as the highest exemplification of totality the artwork becomes the redemptive other that points to the possibility of a world beyond alienation. The affinities to Nietzsche's critique of modern culture are evident. The Theory of the Novel parallels Nietzsche's The Birth of Tragedy from the Spirit of Music. Dostoevsky embodied for the young Lukács the redemptive promise, as did Wagner for the young Nietzsche, of a coming age of authentic culture. The existential truth of the artwork as the utopia of authentic life for the young Lukács or as the defetishizing objectivation of the rgeneric forms of human activity in the late Specificity of the Aesthetic (Eigenart des Ästhetischen [1963]) reveal the underlying continuity of Lukács's pre-Marxist and Marxist thinking about the place and function of art in social life.

It was the young Hegelian Lukács who was so important for Adorno and Benjamin (but also for Bakhtin's own Dostoevsky book, Problems of the Novel), not the unknown Lukács of the Heidelberg manuscripts on aesthetics, written between 1912 and 1918, abandoned by Lukács and not 
published until 1974, edited by György Márkus. ${ }^{3}$ The motivation of the Heidelberg manuscripts remained the crisis of modern culture, but the deciding question was now Kantian: Works of art exist, how are they possible? This question replaces the Hegelian narrative of the loss of authentic culture with the question of the transcendental, that is, systemic, conditions of possibility of the work of art. It meant the acceptance of the ontological tragedy of culture, the acceptance that works of art, like all great cultural objectivations, can transcend alienation, but they cannot abolish it. ${ }^{4}$ Ironically this metaphysical resignation, which confirmed the impossibility of authentic culture and could only be compensated by the retreat to the >redeeming power of form $<,{ }^{5}$ opened up fruitful theoretical possibilities cast aside by Lukács in 1918, which were to find their continuation in Márkus's own theory of cultural modernity.

The presuppositions of Márkus's theory of modern society as the society that knows itself as culture are given in Kant and Hegel's interpretation of enlightened society. Despite their fundamental differences, Kant and Hegel in Márkus's reading share a common sense of the practical limits of Enlightenment. Kant's optimism regarding the existence of a public capable of enlightening itself rested on the conviction that freedom of thought went hand in hand with freedom of trade, specifically a free book market. The public's preference for novels and romances rather than ideas meant, however, that the commercialization of literature had betrayed the ends of Enlightenment. ${ }^{6}$ Kant's optimism was defeated by the gulf between his understanding of the autonomy of the public sphere, defined by the normative roles of author and reader, and the actual interests of authors, readers and thus of publishers. The virtuous circle of the public sphere is shadowed by the vicious circle of private interest: Adorno's analysis of the >culture industry< spells out the dialectic of enlightenment in modern society that is unable to bridge the gulf between the Enlightenment as social-historical project and its practical realisation. ${ }^{7}$

In the essay The Hegelian Conception of Culture, Márkus reconstructs Hegel's understanding of cultural modernity as the end result of the world-historical process of the growth in self-consciousness, the process that Hegel called >Bildung, which covers both collective and individual

7 Adorno: Culture and Administration. 
cultivation. Culture conceived as `Bildung « reflects Hegel's commitment to the fundamental idea of the Enlightenment, »the emancipation of rational and self-determining individuality, for whom the cultivation of reason and will is a value-in-itself «. ${ }^{8}$ But Hegel's autonomous individual, like Kant's self-enlightening public, is a postulate, confined in practice to the few. Even though modernity is the epoch of >Bildung « that knows itself as culture, recognizes its institutions as those created and sustained by human activities, it is nevertheless challenged to effectively realize the reciprocity of individual cultivation and the general culture of society ${ }^{9}$ that had once been the accomplishment and actuality of historical, that is, traditional, cultures. Hegel's dialectic of Enlightenment arises from the two causes that go to the heart of the problem of culture , which so resonated in cultural critique from the Romantics to Nietzsche and Heidegger, Simmel and Weber, and Western Marxism. The one cause lies with the progress of Spirit to self-consciousness, the other in the division of labour and the differentiation of the social totality together with the resultant growth in complexity: The one expresses and reflects the historical process of the dissolution of spiritual unity, the other expresses and reflects the historical process of ever-increasing alienation.

The loss of a spiritual home haunted the nineteenth century and beyond. It turned secularization into the religion of the loss of religion, the religion of mourning for the lost totality of culture. Hegel's concern, lay, however, not with the cultural pessimism of the few but with the socio-cultural gulf that had opened up between the educated elite and the mass of the population, brought about by the decline of religion and shared beliefs. Hegel shared Kant's doubts as to the possibility of a self-determining public. Of the three historical forms of the absolute and the divine - art, religion, philosophy only philosophy could now meet the highest needs of enlightened society. Self-enlightenment remained, however, the privilege and preserve of the few now that religion had lost its socially binding power. For Márkus, the outcome is a deeply paradoxical conception of modernity:

The only society that makes progress into its own inherent principle, and thereby ends shistory can progress only on the basis of a dead cultural tradition, a tradition which its development robbed of spiritual creativity and forced into a merely private sphere. ${ }^{10}$

Modernity's destruction of all cultural traditional is epitomized by the muse$u m$, the bourgeoisie's monument to Hegel's paradox of progress. The cultural treasures of the museum make manifest the spiritual impoverishment of

9 Ibid., p. 408-409.

10 Ibid., p. 413. 
modern individuals, emancipated from traditional bonds. This emancipation signifies for Márkus » the progressive emptying of the individual from all substantive contents and aims « as the alienating consequence of »the progressive transformation of each sphere of the institutional order into an autonomous mechanism which, driven by its objective logic, makes more and more narrow, rigid, and impersonal requirements and demands upon the individual ${ }^{1}{ }^{11}$

It is at this point - the transformation of substance into function (to borrow Ernst Cassirer's title) - that we must pause. Márkus's reconstruction of the contradictions of cultural modernity, exemplified in Kant and Hegel's recognition of the dialectic of Enlightenment, seems to pose impossible obstacles to any possible solution to the ssingle thought ' of culture of the young Lukács and in Western Marxism. And this is indeed the case, there is no ssolution < to the problem of culture when it is conceived in post-Hegelian terms of historical disenchantment. Lukács himself recognised the theoretical impasse when he turned from Hegel back to Kant in his Heidelberg writings on aesthetics between 1912 and 1918. And despite the fact that Lukács had not abandoned his search for an absolute answer to the problem of culture, the central place that the work of art takes in the Heidelberg Philosophy of Art ${ }^{12}$ and the Heidelberg Aesthetics ${ }^{13}$ provides the crucial stepping stone to Márkus's theory of the high culture of modernity.

\section{II.}

Lukács absolutized the work of art as an aesthetic totality of experience, captured in the unity of objective form and subjective spontaneity, comparable to Schelling's >deduction of the art work ‘ in his early System of Transcendental Idealism (System des transzendentalen Idealismus) as the absolute coincidence of subject and object, the conscious and the unconscious. In the earlier Heidelberg Philosophy of Art, the work is grasped as the solution to the fundamental contradictions of life in that it presents qua aesthetic totality the a priori of all actual experience. In the Heidelberg Aesthetics, however, the Kantian question of the conditions of possibility of works of art, as distinct from the fact that works of art exist, can be answered only in the form of a paradoxical absolute, as befits Lukács's own description of the

11 Ibid., p. 407.

12 Lukács: Frühe Schriften zur Ästhetik 1. Heidelberger Philosophie der Kunst (1912-1914). Hereafter cited as Heidelberger Philosophie der Kunst.

13 Lukács: Frühe Schriften zur Ästhetik 2. Heidelberger Ästhetik (1916-1918). Hereafter cited as Heidelberger Ästhetik. 
intention of his aesthetics as a reverent $>$ negative theology $\measuredangle .^{14}$ The condition of the work's possibility resides in the pre-established harmony of form and content. The immanent validity of the work, based on the closed system of the internal relations of its constituent elements, makes it the sole source of value in the aesthetic sphere. Precisely this absolute transcendence of the work in relation to both empirical authors and recipients determines the normativity of production and reception, objectified in the work. The normative relationship between Author, Work, and Recipient, subsumed in the absolute transcendence of the work, presents what we might call the rabsoluter schema of Márkus's own triad of Author, Work and Recipient. Lukács's answer to the Kantian question needs to be >de-theologized ‘ before it can be appropriated, before the turn from Hegel to Kant can be completed. The final step concerns the Lukácsian concept of `form`. As Márkus points out, the concept of form is more comprehensive than that of the sworks:

For Lukács, form designates all the functions connected with the creation of meaning. It enables the multiplicity of facts, events and all the other elements of life to be arranged into meaningful structures, organised patterns of meaning. (Accordingly, form is related not only to the sphere of »absolute spirit« but also to that of »objective spirit «.) ${ }^{15}$

Lukács's concept of form is general enough to encompass and designate not only the congruence of life and works in authentic culture but also the internal principle of objectivation and validity particular to the modern differentiated spheres of the constitution of meaning. In the first chapter of the Heidelberg Aesthetics, Lukács defines his own position as a rejection of Hegel's reduction of all forms of transcendental constitution to one single logical type in favour of the plurality and autonomy of the separate spheres. ${ }^{16}$ If the aesthetic validity of the work of art is still for Lukács absolute, it does not mean, however, as we have seen, that the work of art can abolish alienation. Thus, whether Lukács turns to Hegel or to Kant they only confirm the problem of culture in modernity and hence his own aesthetics and the aesthetic theory of Benjamin and Adorno as negative theology.

The final step from Hegelian substance to (neo-)Kantian function remains to be taken. Between Lukács and Márkus's theory of cultural modernity stands Ernst Cassirer's studies in the conditions of intersubjective validity in the natural and the cultural sciences. ${ }^{17}$ Although Cassirer expanded his early work on epistemological problems in modern philosophy

16 Ibid., p. 235.

17 See the discussion of Cassirer and his 'path-breaking Substanzbegriff: ibid., p. 499-520. 
and sciences ${ }^{18}$ to a general philosophy of symbolic forms covering the arts and the sciences (1923-1929), his crucial contribution for our purposes lies in his functional theory of objectivity, which resides not in the work itself, that is, not in the work's immanent system of relations, but in the system of relations within which the work is itself possible. This functional system of relations in the arts, humanities and sciences constitutes the conditions of production in the high culture of modernity, whose products have for Márkus the following features in common - objectivation, innovation, dematerialisation, and autonomy. ${ }^{19}$ The work as ideal object, that is, as a dematerialized complex of meaning, is for Márkus ‘autotelic , valuable in itself, rautonomous`, independent of external subordination, and rautochthonous , determined by its own internal logic regulated by the normative values of the sphere. These normative values are themselves products of a functional theory of objectivity that requires recognition of the historical relativity of norms. As Cassirer writes:

That we [in science] find only a relative stopping point, that we therefore have to treat the categories, under which we consider the historical process itself, themselves as variable and capable of change, is obviously correct: but this kind of relativity does not indicate the limits but rather the particular life of cognition. ${ }^{20}$

Cassirer's defence and justification of sthe particular life of cognition $>$ is specifically modern, it describes the modern system of culture as one for which historical change, categorical relativity and open-endedness are constitutive. Lukács's conundrum of historicity and timelessness in the artwork that he could only resolve metaphysically ${ }^{21}$ is resolved with Cassirer into the empirical functioning of the cultural and the natural sciences, which derive their intersubjective validity in the case of science by reference to the universal laws of nature and in the case of culture through the possibility of universal meaning that transcends the time-bound nature of cultural creations through the open-ended historical process of reception and re-interpretation. Cassirer's systematization of Kant's two realms of reason and imagination in The Logic of the Cultural Sciences (Zur Logik der Kulturwissenschaften [1942]) forms the epistemological background

20 Cassirer: Das Erkenntnisproblem, p. 16, emphasis in the original, trans. D. R. (»Daß wir in ihr [der Wissenschaft] immer nur einen relativen Stützpunkt finden, daß wir somit die Kategorien, unter denen wir den geschichtlichen Prozeß betrachten, selbst veränderlich und wandlungsfähig erhalten müssen, ist freilich richtig: aber diese Art der Relativität bezeichnet nicht die Schranke, sondern das eigentliche Leben der Erkenntnis. «)

21 Lukács: Heidelberger Philosophie der Kunst, p. 151-232. 
to Márkus's theory of cultural modernity. The two key essays here are $A$ Society of Culture: The Constitution of Cultural Modernity (1994)22 and The Paradoxical Unity of Culture: The Arts and the Sciences (2003). ${ }^{23}$

The two dimensions of Márkus's theory are 1) the structure of validity that is common to the arts and the sciences and allows us to speak of their paradoxical unity and 2) the historicity qua project of the high culture of modernity. I leave the discussion of the historicity of >classical cultural modernity to Part III as it involves the question of the relationship between classical modern and contemporary global modernity, in order to focus here on the unifying conceptual scheme that enables Márkus to articulate the basic similarities and the fundamental differences between the two domains of the arts and the sciences. He calls this scheme the >cultural relation< that embraces the three functional roles of Author-Work-Recipient, each of which is defined by the normative expectations and requirements of the role.

These normative roles, however, do not prescriptively determine the actual character of these practices, nor the effective evaluative criteria of their results. They are (in Kantian terminology) not of constitutive, but only of regulative character. They only indicate delimiting conditions that ought to be met if something is to be regarded as pertaining to the general realm and to a particular domain of culture. ${ }^{24}$

This normativity regulates not only what belongs to the respective domains but equally who has the right to participate. The high, as opposed to the low, culture of modernity is not open to everyone.

Márkus's regulative framework is minimal but it delivers a great deal precisely by refraining from solving the problem of culture doxical unity of culture is underpinned by this methodological abstention, which replaces the grand narratives of the crisis of culture in modernity by the self-regulating constitution of a society of culture. Against the whole German tradition of cultural critique, Márkus defends with Cassirer the Kantian conception of the high culture of modernity as the successor to Hegel's Absolute Spirit. He legitimizes the sparticular life of cognition< of this culture and thereby modernity in its own right against the negations of the legitimacy of modernity explicit or implicit in the cultural pessimism of critical theory in the wide sense.

1. Márkus refuses the narratives of the tragedy of culture, the death of art, which all in their different ways rewrite the Hegelian enlightenment of art in terms of the deadly hostility of science to art. Whether we speak 
of Socratic enlightenment (Nietzsche), alienation and reification (Lukács), disenchantment (Weber), rationalisation (Adorno) or Heidegger's `Gestellk, the progress of the sciences and knowledge is presented as the nemesis of art.

2. The antithetically destructive relationship between the arts and sciences is replaced by the complementarity of the two domains, which is understood as essential to the ongoing vitality and reproduction of high culture. Driven by the ever renewed disputes between the two main ideological programmes of the moderns, Enlightenment and Romanticism, the project of cultural modernity necessarily takes on the general character of critique, constantly tempted, however, to totalizing conclusions that deny the legitimacy of modernity. ${ }^{25}$ Márkus's insistence on the paradoxical unity of culture as the condition of its functioning is directed precisely at the fatal illusions and consequences of all such simultaneously totalizing and one-sided critiques that claim to overcome the antinomies of the modern condition or that in denouncing the dialectic of enlightenment fall victim to the dialectic of romanticism. ${ }^{26}$

3. The autonomy of the arts and the sciences as self-regulating domains, separated from direct social functions, insulates normativity from all overriding external demands at the same time as it makes normativity a function of the evolving and changing historical system. Márkus's account is thus in no way tied to a terminal vision of modernity and the decadence of its culture. There are no gods, old or new, waiting to save us. Rather, the high culture of modernity is a historical phenomenon that is classical because it came closest to realizing the Kantian conception of modern society as a society of culture. Its historical limits indicate the remit of Márkus's theory but not the limits of the evolving and changing cultural creativity and self-understanding of modern society. If this was not the interest or focus of Márkus's published writings on culture (even though he had long worked on a comparative analysis of theories of mass culture), they do contain highly relevant pointers towards theorizing contemporary culture.

\section{III.}

Márkus's reconciliation of normative structure and historical system is itself, however, historical. His theory describes the high culture of

26 See Roberts/Murphy: Dialectic of Romanticism. 
classical (European) modernity from the late eighteenth century to the end of the Second World War. The two key distinctions of his theory are that between the arts and the sciences and that between high and low culture. As we have seen, the vitality and capacity for self-reproduction that defined high culture came from the productive tension between and essential complementarity of the two domains of the arts and sciences. There was no such productive complementarity, however, between the spheres of high and low culture, produced and reproduced primarily by the segmentation and commodification of the market for cultural goods. But in both respects the culture of classical modernity was built around processes of differentiation, normative in relation to the arts and sciences, economic in relation to the separate interests of recipients of high and low culture. This basic structure of differentiation still applies to contemporary culture, but it no longer plays the defining role that it did for modern culture. The arts and the sciences still constitute separate domains, they still retain their normative criteria, even though they can no longer police and autonomously determine their borders as they once could. This erosion of borders points to the new forms of de-differentiating dynamics reshaping contemporary culture that are tied up with the penetration of the life world by aestheticization and scientization. We could say that the paradoxical unity of high culture has dis/appeared into the diffused ubiquity of scientific and aesthetic attitudes.

Science and the scientific attitude have provided the dominant ideology of modernity since the Enlightenment. The social effects in the form of the rationalization of the workplace and the bureaucratization of organizations have taken on a new competitive intensity since the Second World War and the progressive universalization of the developmental model of the nation-state. The same processes of competitive rationalization are at work in the aesthetic colonization of the life world in relation to products and consumers. This operative complementarity only becomes culturally interesting, however, when this dual penetration of work and leisure takes on a new quality through the inter-penetration of aestheticization and scientization to produce possibilities of creative hybridization that mirror and are mirrored in the inter-penetration of high and low culture. To sum up these introductory comments: The paradoxical unity of high culture has been transformed into the paradoxical unity of high and low culture - a unity, defined not by the complementarity of the differentiated spheres of the arts and sciences but by their inter-penetration as it is reflected in contemporary culture on the level of both content and form. As regards content, I am thinking here of the importance of science-fiction for crit- 
ical reflection on science and technology, as regards form I am thinking of the appropriation of the creative possibilities of technology in the arts.

The causes of the disintegration of the high culture of modernity are manifold, but they can be summed up in terms of the erosion of the normative criteria of its two domains from both internal and external reasons. In A Society of Culture Márkus lists some of the key factors that have made the classical conception of high culture inapplicable to contemporary practices. De-objectivation undoes the idea of the work as a self-subsisting ideal object, dissolving it into unlimited data in the sciences or into ephemeral event or happening in art; rematerialization reduces the work as a meaning-complex to a series of self-referential operations in science or to an object in art that foregrounds the material media of communication. In relation to the author, novelty is divorced from the creative subject, who disappears into the multiple authorship of scientific papers or whose death is proclaimed in art. In relation to reception, Márkus stresses the loss of autochthony and the consequent vitiation of the formal normative autonomy of the two domains, which he illustrates by reference to the effective suspension of the intersubjective validation of research results in the sciences under the pressure of the costs of verification and the interests of external funding. ${ }^{27}$ Although the modern arts have always been dependent on the art market and old and new forms of patronage, it is clear that the normative distinction between aesthetic and market criteria has largely lost its purchase. All these factors are negative indices of the decline and dissolution of the high culture of modernity. Nevertheless, despite the importance of the external influences of money and power at work here, we need to recognize that the internal processes dissolving the boundaries of high culture express the dynamics of historical change inherent in the Enlightenment conception of culture.

Emblematic of these changes is the transformation of the status of the artwork. In Lukács and Márkus, the work occupies the central place as the synthesis of production and reception. Modern aesthetic theory is the theory of the work of art as thing, as discrete object, and of works of art as the sole province of theory. The original meaning of aesthetics as referring to sensuous perception was thus narrowed down to the normative criteria of judgment that served to determine the borders of art proper from the crafts, handiwork, design and decoration or `Kitsch $<$. Aesthetic theory in this sense went hand in hand with the modern differentiation of the arts as a separate domain. The dis/appearance of the aesthetic sphere into aestheticization of the lifeworld is reflected in the dis/appearance of the artwork 
into ambient happening, event, performance. Both are symptomatic of a fundamental process of de-differentiation that calls for a recovery of the original meaning of aesthetics as sensuous perception. This is the gist of Gernot Böhme's argument for a new aesthetics that responds to aestheticization and that has as its focus the production of atmospheric aura as opposed to auratic artworks. ${ }^{28}$

The works of cultural modernity are premised on the idea of originality, just as the idea of originality presupposes the existence of a tradition from which the new work departs. Conceived in terms of originality, tradition takes on two fundamental characteristics: It is a living tradition but one whose compass is constantly expanding. For the moderns, the aesthetic legacy has become a readily accessible source for recipients and an imaginative resource for artists, progressively incorporating the arts of the past in all their variety and forms. ${ }^{29}$ As Márkus writes in The Paradoxical Unity of Culture, whether one understands this expansion of aesthetic tradition as a sign of the "incredible openness " or of the »insatiable cultural imperialism « of the moderns:

The history of modern art is also that of the recovery and absorption of forgotten or alien pasts - and this process is still going on. [...] Tradition now lacks what it was always meant to be - a binding force for contemporary practice. But as the power of tradition dissipates, its weight constantly increases. ${ }^{30}$

Márkus sums up this dialectic of historicization together with the corresponding double transgression of the boundaries of art as follows:

This acceleration and radicalisation of the production of novelty, however, only contributes to the expansion of the musealised tradition, which spurs it on. As the temporal distance between the outdated old and the radically new becomes ever shorter, the life-span of the new, in which it counts as novel, of contemporary relevance, diminishes too. The more radical the novelty the more rapidly it becomes musealised. The more artistic practice seems to approximate to the state of permanent revolution, the more the art work of the future turns immediately into the artwork of the past. ${ }^{31}$

Contemporary art does not exist in isolation, it is part of a global market for art and entertainment, which in turn is part of a global consumer market for tangible and intangible goods, animated by advertising, an event- and experience-culture, and tourism. The global art and entertainment industries, the culture and creative industries have comprehensively refashioned the cultural institutions of Western modernity - museums, galleries, opera

29 Márkus: Culture, Science, Society, p. 66.

30 Ibid.

31 Ibid. 
houses, concert halls (along with universities) into commercial enterprises. Warhol was perhaps the first to have recognized that the two distinct functions of the museum and the department store were on the way to the paradoxical unity that has been consummated in the contemporary museum. It is no surprise that museums have achieved their greatest public success over recent years with the staging of exhibitions of fashion, which register the spectacle of the contemporary as the reternal return of the new $<$. In turn digitalization has subsumed the genres of modernity - drama, novel, film, video games, information, news - in the one universal medium streamed into the home or mobile phone. The World Wide Web makes the art, architecture, literature of the world available. Malraux's imaginary museum of world art has become virtual reality in the cloud.

Can we still speak of contemporary culture as a Kantian project? I would like to suggest that the answer is yes, that despite the striking discontinuities the continuities are more significant and that we can indeed speak of an extrapolation of Márkus's theory of cultural modernity. Modern and contemporary culture share the dialectical relationship with traditional culture that Márkus describes in Antinomies of Culture:

[...] [F]rom the viewpoint of the broad concept of culture, modern society appears as essentially deficient. But at the same time - and from the perspective of this very same concept - modernity takes on the character of the paradigmatic or >most fully developed c culture because it is the culture which self-reflexively knows itself as culture. By recognizing all others as equal cultures, cultural modernity posits itself as more equal than others. It is its very particularity - that is, its self-reflexive character - that makes it universal: the recognition of other societies as >cultures confers on it the task and the right to assimilate/acquire/take into possession their `cultural achievements $<$ - of course, what it qualifies as such. ${ }^{32}$

This »right" and this "task « have now been taken over by the community of nations, who recognize, as indicated above, their common responsibility to preserve the natural and cultural heritage of mankind. It is a mark of the ongoing de-colonizing phase of globalization set in train by the Second World War, opening the way to the co-evolution of world society and the nation-state.

Since 1945, some 140 new nation-states have been established, constructed by external cultural processes, which provide the global models for implementation of rationalized modernization (constitution, citizenship, educational system etc.), which the old civilizational patterns, religions and even fundamentalist rejections of universalistic modernization cannot resist and must adapt to. So, globalization and nation-states go together as 
the contemporary post-civilizational form of world society, ${ }^{33}$ in which rationalized modernity, according to John Meyer and John Boli, has become the »universalistic and inordinately successful form of the earlier Western religious and post-religious system «:

The elites of world society share the belief that salvation lies in rationalized structures grounded in scientific and technological knowledge. The new religious elites are the professionals, researchers, scientists, and intellectuals who write secularized and unconditionally universalistic versions of the salvation story [...] This belief is worldwide and structures the organization of social life almost everywhere. ${ }^{34}$

In one significant respect, however, there is a marked break between the modern and the contemporary. For Márkus, the intellectual was the prime carrier of the ideas of the Enlightenment and of the modern conception of society as culture. This is no longer the case. Intellectuals and modern intellectual culture have been pushed aside by the »the new religious elites" of world society now that the projects of Enlightenment and Romanticism have increasingly lost their relevance for "a very specific, a single group of social actors: the intellectuals «. ${ }^{35}$ Here Márkus has in mind the sspecialists in cultural critique. It was they who "spearheaded the feuding projects of Enlightenment and Romanticism « ${ }^{36}$ Today they are no longer needed. Their role has been taken over by the genuine experts: »the managers and PR persons of various cultural institutions and media, and their patrons and allies in social and political establishments $«{ }^{37}$ Does this mean the end of what Márkus calls the often uneasy but persistent connection between culture and critique in modernity? Is rationalized modernity the conclusion rather than the continuation of the project of Enlightenment? Or were Márkus's intellectuals the last to be secularized in the present post-civilizational form of world society, based on the new sacred texts of the gospel of scientific-technological salvation that announces a new global technological civilization? These are not questions that I can answer. I can say, however, that Márkus's theory of cultural modernity forms a legacy that surely has a role to play in the analysis of the paradoxes of global contemporary culture. 


\section{References}

Adorno, Theodor W.: Culture and Administration. In: The Culture Industry. Ed. J. M. Bernstein. London: Routledge 1991.

Böhme, Gernot: Atmosphäre. Essays zu einer neuen Ästhetik. Frankfurt/M.: Suhrkamp 2013.

Cassirer, Ernst: Das Erkenntnisproblem in der Philosophie und Wissenschaft der neueren Zeit, Vol. 1. Berlin: Cassirer 1906.

Cassirer, Ernst: The Logic of the Cultural Sciences. New Haven: Yale University Press 2000.

Fehér, Ferenc; Heller, Agnes; György, Márkus: Dictatorship over Needs. Oxford: Blackwell 1983.

Lukács, Georg: Die Seele und die Formen. Essays. Mit einer Einleitung von Judith Butler. Bielefeld: Aisthesis 2011.

Lukács, Georg: Frühe Schriften zur Ästhetik 1. Heidelberger Philosophie der Kunst (19121914). In: Werke, Vol. 16. Ed. György Markus. Neuwied: Luchterhand 1974.

Lukács, Georg: Frühe Schriften zur Ästhetik 2. Heidelberger Ästhetik(1916-1918). In: Werke, Vol. 17. Ed. György Markus. Neuwied: Luchterhand 1974.

Lukács, Georg: Die Eigenart des Ästhetischen. Neuwied: Luchterhand 1963.

Márkus, György: Culture, Science, Society. The Constitution of Cultural Modernity. Leiden: Brill 2011.

Márkus, György: Marxism and Anthropology. The Concept of »Human Essence" in the Philosophy of Marx. Assen: Van Gorcum 1978.

Meyer, John W.; Boli, John; Thomas, George M.; Ramirez, Francisco O.: World Society and the Nation-State. "American Journal of Sociology" 103/1 (1997), pp. 144-181.

Redner, Harry: Beyond Civilization. Society, Culture, and the Individual in the Age of Globalization. New Brunswick: Transaction 2013.

Roberts, David; Murphy, Peter: Dialectic of Romanticism: A Critique of Modernism. London: Continuum 2004. 